\title{
CORONAVIRUS IMPACT ON ONLINE PURCHASES BEHAVIOR IN JAPAN
}

\author{
Alias Abdullah ${ }^{1}$, Mohd Shahrizal Azhari², \\ Aimi Aqilah Mohamad Yusoff ${ }^{3}$
}

The COVID-19 outbreak has impacted almost every aspect of people's lives Japan. With the aging society that more vulnerable to the disease that needs most people to stay home, Japanese have been adapting to both the outbreak and the regulations. The declaration of state of emergency since April makes the businesses and stores deemed non-essential to limit their operations. To limit places where people could gather, all schools, institutes of higher learning, and houses of worship were ordered to be closed during the period. Japanese have been spending more time online and have shown more willingness to purchase items online now. Changes in behavior such as needing to work from home or exploring new hobbies while staying at home also present new opportunities for eCommerce. COVID-19 is having a catastrophic impact on many non-essential products in Japan. With the environment being so different to pre-COVID time, COVID-19 has impacted Japanese eCommerce industry in some ways. COVID-19 pandemic creates new environment for the Japanese shopping and spending behavior that needs to be discussed further.

Keywords: eCommerce, COVID-19, supply, online purchasing, spending behavior

\section{INTRODUCTION}

On January 16, 2020, the first coronavirus (COVID-19) case was registered in Japan and earlier cases were reported which were among the travelers from the Wuhan, China area and the returnees. Thus, actions to prevent the spread of the virus were ultimately developed by the Japanese government. The proposed Tokyo Summer Olympics 2020 were postponed to 2021, as the infection cases counts rose up. On February 27, Prime Minister, Shinzo Abe ordered school closures and declared a state of emergency for Tokyo and six prefectures and continued to be

\footnotetext{
${ }^{1}$ Senior Lecturer, Department of East Asian Studies, Faculty of Arts and Social Sciences, University of Malaya, Kuala Lumpur, Malaysia. Email: dralias@um.edu.my

2 a Ph.D student at the Department of East Asian Studies, Faculty of Arts and Social Sciences, University of Malaya, Kuala Lumpur, Malaysia. Email: moshaz02@yahoo.com

${ }^{3}$ Aimi Aqilah Mohamad Yusoff is a former student at the Department of East Asian Studies, Faculty of Arts and Social Sciences, University of Malaya, Kuala Lumpur, Malaysia. Email: eimieyaimi@gmail.com
} 
applied to the other part of the country. On May 20, Tokyo and seven prefectures remained in the state of emergency with 16,386 confirmed COVID-19 cases and 771 deaths were reported. ${ }^{4}$ According to the World Health Organization, on 11 March 2020, Coronavirus (COVID-19) was officially declared as a pandemic that has happened to spread all over the world and the World Health Organization has notified the public to take measures in controlling the spreading of the virus including social distancing measures. ${ }^{5}$ Due to the outbreak of coronavirus (COVID-19) pandemic, Japan took measures in controlling the spread of the virus and as well as taking measures to keep the economic sectors intact despite being affected by the pandemic.

While the pandemic has restricted the society from doing outdoor activities, the public has turned to doing their activities indoors and taking part to control the spreading of the virus. The increasing cases of COVID-19 in Japan have made a significant change in the lifestyle in Japan. One of them is the decline in the use of services that required face-to-face communication. The consumption habits among Japanese people have changed dramatically due to the spread of the coronavirus. The consumption habits include the purchasing behaviors of the Japanese people. Due to the social distancing and decline in face-to-face communication, people in Japan choose to do their purchasing through the internet.

According to Tsutomu Watanabe and Yuki Omori, for the purchasing of goods, there has been a significant rise in transactions through the internet in online purchases platforms named ecommerce. There has been a trend to avoid face-to-face communication in the case of consumer products such as at the supermarkets and convenience stores for example, the rising amount for spending per customer but the declining number of shoppers in regard to supermarket shopping. In the midst of the pandemic, the consumers have changed their demand from face-to-face to non-face-to-face purchasing activities due to their concern about their health and the spread of the coronavirus (COVID-19) that has restricted people from going outside freely. The demands from the national and local government for self-restraint have made the trend of non-face-to-face activities rising up. ${ }^{6}$

Eventually, the trend of non-face-to-face activities has made the consumers in Japan turn in favor of the online purchases in e-commerce markets to purchase items or daily essentials. The consumers will make their transactions through the internet and their purchased items will be delivered directly to their homes which is a way to avoid making a crowd in shops or markets that will jeopardize their health in regard to the spread of the coronavirus (COVID-19) in Japan. The COVID-19 pandemic has made an impact on the e-commerce sector in Japan that has also affected the online purchases behavior among consumers in Japan. Online purchases behavior among consumers in Japan due to the impact of the coronavirus (COVID-19) can be explained through the growing consumption of e-commerce in Japan during the pandemic, the statistics of online purchases in Japan and also factors of why consumers have chosen to do online purchases in Japan. More than that, the challenges faced in online purchasing which mostly affect retailers during the pandemic COVID-19.

\footnotetext{
${ }^{4}$ Shigemura, Jun, and Mie Kurosawa, "Mental Health Impact of the Covid-19 Pandemic in Japan," Psychological Trauma: Theory, Research, Practice, and Policy, Vol. 12, No. 5 2020, p. 478.

${ }^{5}$ WHO Director-General's Opening Remarks at the Media Briefing on Covid-19, World Health Organization (WHO), 11 March, 2020, available at: https://www.who.int/director-general/speeches/detail/who-director-general-sopening-remarks-at-the-media-briefing-on-covid-19---11-march-2020, accessed on 15 January, 2021.

${ }^{6}$ Tsutomu Watanabe, and Yuki Omori, "Online Consumption During the Covid-19 Crisis: Evidence from Japan," Covid Economics - Centre for Economic Policy Research Papers, Vol. 38, No. 16, 2020, pp. 218-252.
} 


\section{GROWTH OF E-COMMERCE MARKET IN JAPAN DURING PANDEMIC}

The spread of the coronavirus (COVID-19) has made a significant impact in the e-commerce market due to the rising trend of online purchasing by the consumers in Japan. Electronic commerce or e-commerce is defined by the World Trade Organization as the production, distribution, marketing, sale or delivery of goods by electronic means. ${ }^{7}$ According to Amyn Gillani, Japan has a remarkable growth of e-commerce and is expected to continue to grow actively in the years ahead. Japan's e-commerce market is known to be among the world's fastest-growing while boosted by a highly developed economy, highly urbanized population, strong internet penetration with single-language culture. Thus, Japan ranked in the top five of the largest e-commerce markets in the world consistently. The excellent infrastructure topped by the small size of the country has enabled fast delivery which often benefits the e-commerce businesses. ${ }^{8}$

The E-commerce market in Japan is mainly categorized into three sectors, retail, digital and services. ${ }^{9}$ The biggest market is the retail market in which most consumers will turn to ecommerce websites in Japan that offer retail shopping to buy goods and daily essentials. Ecommerce websites in Japan play a vital role in the growth of online purchases among consumers in Japan. These include remarkable performance by the e-commerce companies in offering their service to provide and sell products to consumers by delivering them direct to their homes besides avoiding face-to-face communication in the midst of the pandemic. Among the top e-commerce companies during 2020 which have earned more than $50 \%$ of the country's annual revenue are Amazon Japan, Yahoo Japan and Rakuten. ${ }^{10}$ These companies have been the leading e-commerce platforms in Japan. These companies offered significant services to the consumers in Japan in providing online purchase websites enabling a remarkable transaction through the internet. Through these websites also, the consumers are able to have access to a range of products including electronics, furniture and their essential items.

Fishing industry in Japan is also using e-commerce in marketing fish supplies to consumers all around the country due to the decline in demand for dining out during the pandemic. According to a report by the Japan Times, there are many consumers who are seeking to enjoy the taste of high-quality fish from Japan's largest fish market that only chefs and other professionals have been able to obtain before, while chances to stay at home increase in the midst of the on-going coronavirus pandemic. Thus, fish wholesalers at the Japan's largest fish market, Toyosu Market, are boosting their operations in online sales for products used in high-

7 Electronic Commerce, World Trade Organization (WTO), May 20, 1998, available at: https://docs.wto.org/dol2fe/Pages/SS/directdoc.aspx?filename=q:/WT/MIN98/DEC2.pdf\&Open=True, accessed on 15 January, 2021.

8 Amyn Gillani, Japan: An Overlooked E-Commerce Opportunity, Entrepreneur Asia Pacific, 6 April, 2020, available at: https://www.entrepreneur.com/article/348787, accessed on 15 January, 2021.

9 Wakana Morlan, Selling in Japan: E-Commerce Landscape in Japan, 2 July, 2019, available at: https://blog.btrax.com/e-commerce-trends-in-japan/, accessed on 15 January, 2021.

10 Japan Ecommerce Market, MobileCommerce, Retail, Electronics \& Media, Toys, Hobby \& DIY, Furniture \& Appliances, Food \& Personal Care, Digital Services, Company Analysis. Renub Market Report, June 2020, available at: https://www.researchandmarkets.com/reports/5115530/japan-ecommerce-market-mobilecommerceretail?utm_source=BW\&utm_medium=PressRelease \&utm_code=qktf2s\&utm_campaign=1417043+-+Japan+e-

Commerce+Market+Outlook+2020-2026+-

+ Amazon+Japan $\% 2 \mathrm{c}+$ Yahoo+Japan\%2c+and+Rakuten+Earn+More+Than $+50 \% 25+$ of + the + Country $\% 27 \mathrm{~s}+$ Yearly + Revenue\&utm exec=joca220prd, accessed on 15 January, 2021. 
end sushi restaurants such as sea urchin and bluefin tuna. The wholesalers and intermediate wholesalers participating in the selling at Toyosu Market are using e-commerce to reach out to the general public by selling fish directly to customers which has expanded rapidly in the aftermath of the coronavirus pandemic.

For example, a wholesaler participating in tuna auctions at Toyosu Market, Chuo Gyorui Co. collaborated with Shokubunka, a Tokyo company which runs an online shopping website for some 700,000 users to raise its seafood sales. Other than that, the Inaseri Fish Market, an online shopping site was opened in May by the Tokyo Fish Market Wholesale Cooperative, a group of around 400 intermediate wholesalers in Toyosu. The cooperative also has a website run operated along with an IT company, for restaurants to buy fish. The decline in demand for dining out in the wake of the coronavirus pandemic downturn, has led the company to focus on catering the customers directly as well. Therefore, the Inaseri Fish Market provides a set of fresh fish such as mackerel, alfonsino and squid picked by wholesalers as the recommendations of the day for the customers. A video guide on how to clean and fillet fish was also provided on the website and it was reported that the number of repeat customers are rising as well. ${ }^{11}$

The rise of food e-commerce indicates the growth of the e-commerce market in the food sector in the midst of the coronavirus pandemic. The upsurge in coronavirus cases in Japan has made the food shoppers or consumers to join the bandwagon in purchasing groceries items in the online stores. According to the report by The Asahi Shimbun, a huge number of Japanese customers have started to go online during the outbreak of coronavirus and made a significant shift for the country due to the expectation of the slow-motion in embracing online food shopping before this. Therefore, Japan has started to adopt grocery e-commerce that has sent retailers such as Aeon Co. working hard to meet the rising demand in delivery. Retail managers and researchers have believed that internet sales currently account for nearly 5 percent or more of overall grocery sales in Japan compared to 2.5 percent before the outbreak of the coronavirus pandemic.

Despite the years in talking about the slow growth in online purchases, most of the Japanese supermarkets only started to spend on the infrastructure of e-commerce on a large scale recently. This is because they have to meet the sudden demand from the consumers in the country and most of the supermarkets are struggling in securing a fast and efficient delivery of their products. For example, the retail giant in Japan, Aeon, was said to need to hire more workers in packing their online grocery orders even though they still struggled in hiring more drivers to deliver the orders. However, Aeon expects a growth in online grocery sales by 50 percent despite the struggles that have to go through. The rise in food e-commerce during the outbreak of the pandemic has also sent most business executives and analysts expecting the shift in the online grocery shopping will last even after the end of this pandemic. According to Ocado Jensen, a chief executive from Ocado Solutions, in the rising use of online, people in Japan will stay with online purchasing rather than going back and there is an expectation of a speedy growth of e-commerce. ${ }^{12}$

The growth of e-commerce during the coronavirus pandemic has caused a remarkable shift in the fashion retails sector. Fast fashion chain companies have started to boost investment and shift its logistics to expand their sales in e-commerce in Japan. According a report by Keiichi

11 Toyosu Market's High-End Fish Going Online, Japan Times, 2 December, 2020, available at: https://www.japantimes.co.jp/news/2020/12/02/business/toyosu-online-fish-market/, accessed on 15 January, 2021.

12 Japan's Fussy Food Shoppers Finally Go Online Amid Pandemic, Asahi Shimbun, 30 June, 2020, available at: http://www.asahi.com/ajw/, accessed on 15 January, 2021. 
Furukawa (2020), Uniqlo's owner, the Fast Retailing has started to boost their investment in online shopping and followed by other Japanese retail group which shows that they are running to meet the demand in online shopping caused by the changing consumers' behaviors due to the outbreak of the coronavirus pandemic. The investment by Fast Retailing includes the completion of an automated warehouse in the Osaka Prefecture city of Ibaraki for e-commerce to enhance their delivery services in which they can deliver orders within three days. Uniqlo has spent an estimation of 26.6 billion yen on computer systems for e-commerce and other activities in emphasizing their investment in e-commerce. ${ }^{13}$

\section{Figure 1: The Fast-Retailing Spending on E-Commerce through the Years}

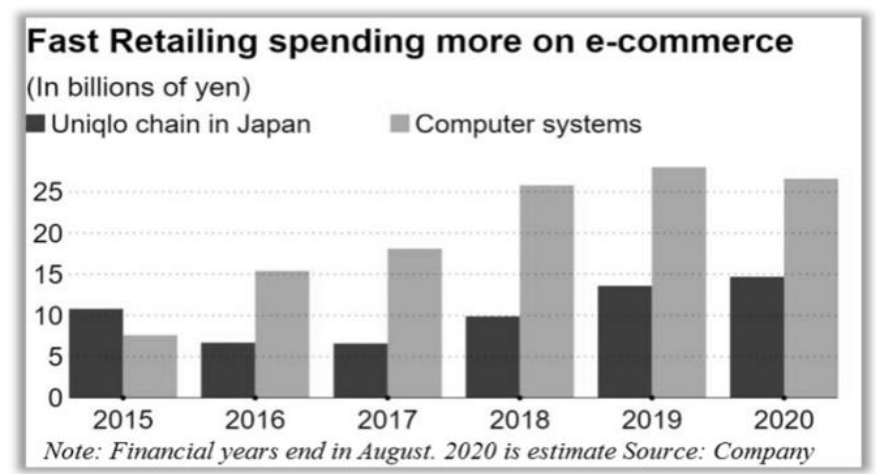

Source: NIKKEI Asia, available at: https://asia.nikkei.com/Business/Retail/Uniqlo-boosts-investment-in-ecommerce-in-Janan-and-China.

Following the growing investment from Japan retails shops especially in expanding their delivery services through building well-functioned automated warehouses for e-commerce, the convenience retailing sector has also adopted the online services for the customers. For example, Japan's biggest convenience store chain, the Seven-Eleven Japan, started to launch a fast home delivery of merchandise from their outlets to cater for the customers' demands. This adoption of home delivery due to the rise of online clothing and convenience items purchases was due to the changing consuming behaviors' in the midst of the outbreak of the pandemic. Trying to avoid going outside to shop publicly, customers have chosen to shop online and wait for their stuff to arrive directly to their doors while the stuff is still fresh and can prevent themselves from getting caught by the virus or spreading the virus as well. ${ }^{14}$

E-commerce in Japan has also shown a significant growth by emerging their services with the utilization of digital technologies to cater for the high demand in online shopping among the consumers in Japan. E-commerce companies in Japan have come out with new ideas in providing the best services to deliver their products directly to their customers because the number of physical shoppers has declined due to the outbreak of pandemic and most of the customers have turned into online shoppers. According to the CEO of Rakuten Inc, Hiroshi Mikitani, there is a growing demand for online services due to the request from the government for the public to stay at home which has reduced demand for traveling. Thus, there is a rising

\footnotetext{
${ }^{13}$ UNIQLO Boosts Investment in E-Commerce in Japan and China, Nikkei Asia, 15 September, 2020, available at: https://asia.nikkei.com/Business/Retail/Uniqlo-boosts-investment-in-e-commerce-in-Japan-and-China, accessed on 15 January, 2021.

14 Ibid.
} 
number of consumers on e-commerce to buy daily essentials and web-based securities trade besides video conferences on social media and viewership for videos and sports events. Rakuten is boosting up its electronic payment services to support the push for cashless or online transactions by the government. Furthermore, people have become reluctant to touch cash because of the outbreak of pandemic and they would prefer to do smartphone-based payments which have now become popular among the people in Japan. ${ }^{15}$

Other than that, most retail companies in Japan have started to boost up their utilization in digital technologies in order to make up for their losses in gaining customers physically due to the high number of people starting to shop online. In order to gain more customers, Takashi Sawada, the president of FamilyMart Co. was planning to add the number of Amazon Hub parcel lockers sevenfold to about 350 by the next two years at its outlets. In about 50 stores, Family Mart has installed Amazon Hub lockers for consumers to pick up their ordered items they purchase from online shopping services from Amazon Japan G.K in hope to attract much more customers. This decision was made to cover the falling number of shoppers for Family Mart stores while there is an increasing demand for online shopping amid the outbreak of coronavirus pandemic. Other than that, Family Mart wants to make an improvement in their performance in the utilization of digital technologies in hope to increase their profits by their eagerness in expanding the use of its FamiPay e-money application. ${ }^{16}$

\section{Figure 2: FamiPay allows money transactions through smartphone wallet} application

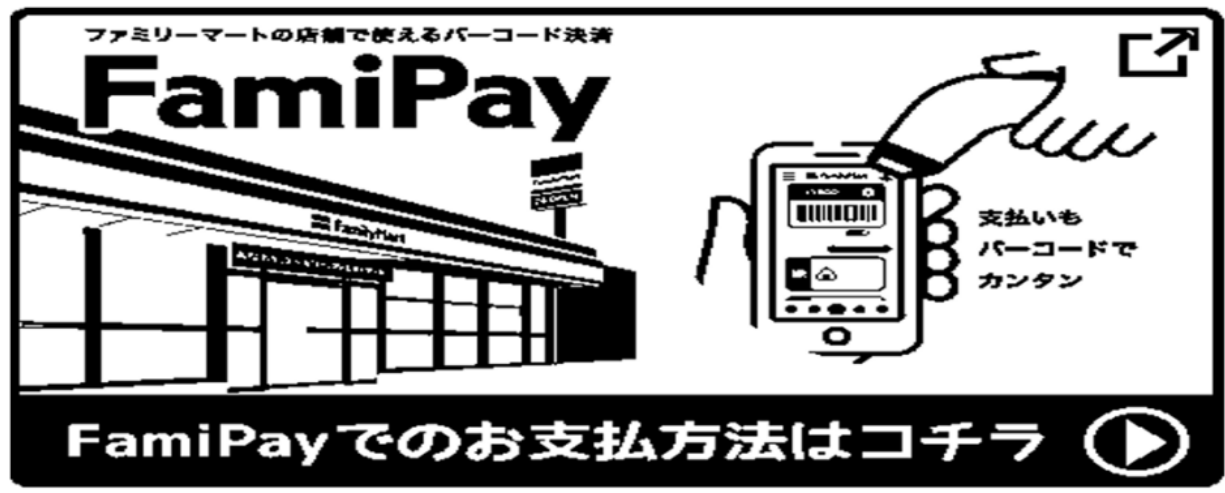

Source: https://www.family.co.jp/services/payment/famipay.html?wovn=en

Therefore, the growing use of e-commerce in Japan was encouraged by the government's push for the public to stay at home amid the coronavirus pandemic. Consumers in Japan have turned into online shopping to purchase their daily essentials and other services and made the payment through online transactions while avoiding face-to-face contact in hope to prevent the

15 Covid-19 Pandemic Prompts a Digital Revolution, Japan Times, 15 April, 2020, available at: https://www.japantimes.co.jp/opinion/2020/04/15/commentary/japan-commentary/covid-19-pandemic-promptsdigital-revolution/, accessed on 15 January, 2021.

${ }^{16}$ Familymart to Increase Stores with Amazon Lockers Sevenfold, The Japan Times, 28 December, 2020, available at: https://www.japantimes.co.jp/news/2020/12/28/business/corporate-business/familymart-increase-stores-amazonlockers-sevenfold-president/ , accessed on 15 January, 2021. 
spreading of the coronavirus. Many e-commerce companies have made new ideas and enhanced their services in online shopping and delivery service to cater for the customers' demand in hope to attract more buyers and made up for the losses in the number of customers visiting physical stores. Thus, the growth of the e-commerce market during the coronavirus pandemic in Japan has encouraged the people in Japan to make online purchases and this has affected the online purchase behavior among the consumers in Japan.

\section{STATISTICS OF ONLINE PURCHASE IN JAPAN}

Even though Japan is the third biggest ecommerce market in the world after the USA and China, it is not popular with foreign online shoppers since the cross-border purchase rate is low and the approach to online shopping is a little bit unusual. Japanese consumers who buy goods on foreign websites only consist of $10 \%$ of Japan's population.

Statista, a research firm, estimated that Japanese ecommerce global sales will amount to $\$ 100$ billion in 2020 which is a low estimate since global economic changes ${ }^{17}$. Sales tax increase in 2019 from $8 \%$ to $10 \%$ also is affecting consumers from spending online. In the first quarter of 2020, Japanese economy continues to shrink and Japanese consumers who are known for sticking to a specific brand are now willing to try new brands because of cost consciousness.

Figure 3: Estimation of Global Ecommerce Sales in 2020 (USD)

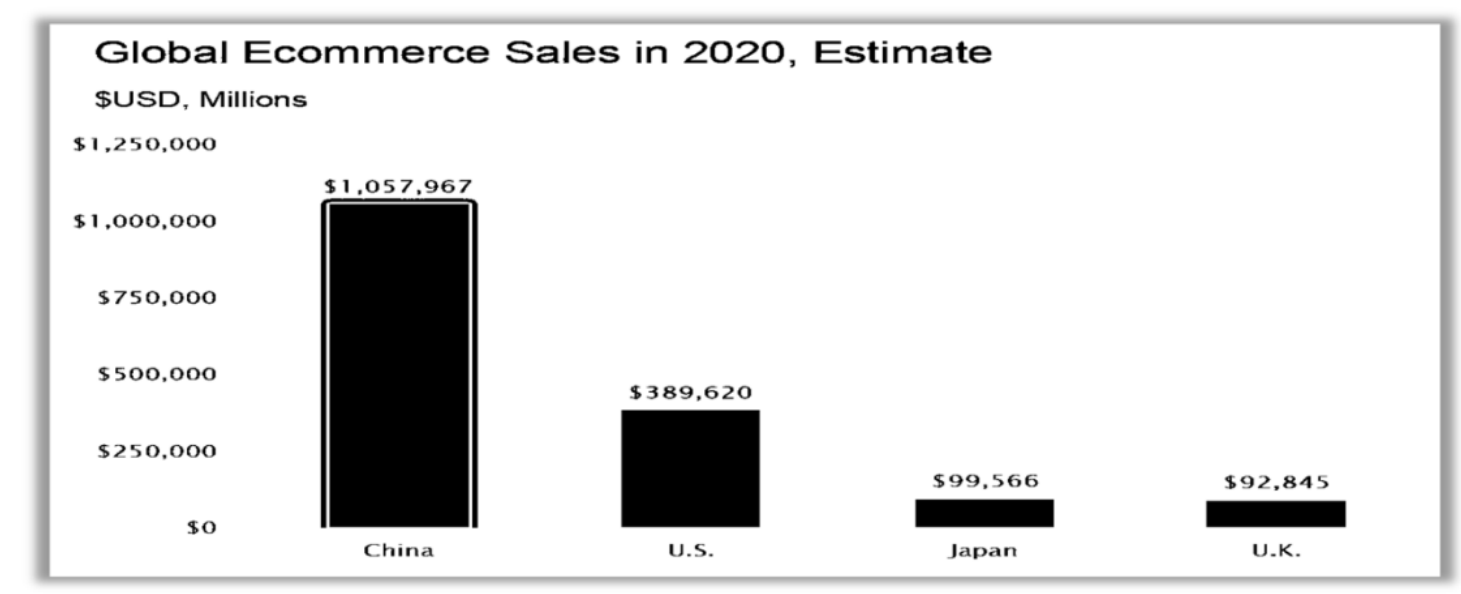

Source: Practical Ecommerce. https://www.practicalecommerce.com/japan-is-a-enticing-market-for-cross-border-

Japan consumer's perspectives on economic recovery from the pandemic are less negative than in April 2020 but still more increase in pessimism from September $2020^{18}$ since

\footnotetext{
${ }^{17}$ Marcia Kaplan, Japan Is an Enticing Market for Cross-border Ecommerce, PracticalEcommerce, 28 May, 2020, available at: https://www.practicalecommerce.com/japan-is-a-enticing-market-for-cross-border-ecommerce, accessed on 15 January, 2021.

18 Katherine Chan, Megumi Inoue, and Naomi Yamakawa, Survey: Japanese Consumer Sentiment during the Coronavirus Crisis, McKinsey \& Company, 10 December, 2020, available at: https://www.mckinsey.com/businessfunctions/marketing-and-sales/our-insights/survey-japanese-consumer-sentiment-during-the-coronavirus-crisis, accessed on 15 January, 2021.
} 
they believe that it will take sometimes before their usual routines and finances return to normal. The trend to purchase online is not dramatic in Japan compared to other APAC countries but still online purchase continues to be the popular choice for consumers. These had accelerated new digital and low touch shopping behaviors' such as restaurant delivery, self-checkout, and online purchasing for in store pick up since before the pandemic, these categories are not really trending in Japan. Retail traffic however, fell 63\% from normal in Tokyo only last April 2020 according to mobile data analyzed by Google.

The global pandemic has accelerated the shift to online shopping. The data showed from Japanese data analytics company Nowcast and credit card issuer JCB that e-commerce sales have increased more than 20\% in Japan since April 2020. According to Boston Consulting Group, $46 \%$ of Japanese consumers stated that they will continue to purchase online and $14 \%$ of them will do it for perishable food after the Japanese government lifted the emergency for Covid 19.

Due to Covid 19, there are four fundamental shifts to consumer behavior that will have a lasting impact even after the pandemic is over. Up to 20 percent of online consumers stated that they will decrease spending on discretionary categories like golf, fishing and instead shifting to values and essentials such as foods and clothes. Next, up to 20 percent of consumers have the intent to stay with online purchasing even after Covid 19 ends. Moreover, Japanese consumers also began to try brands or stores that they previously did not use to go. Lastly is the Homebody economy as 71 percent of Japanese consumers are not yet continuing normal out of home activities.

According to the Malaysian newspaper, The Star $^{19}$, Shun Iwata, 51, an individual who is used to shops in physical stores and eats out during the week, converted to online shopping. The reason why he did not like online shopping at first was that he was concerned over his own privacy. However due to Covid 19, he started to buy masks and disinfectant online because stores were sold out. Now it has become his routine to shop online for various things. He stated that "There's a lot of things you can get online that you can't find in the stores."

\section{FACTORS OF ONLINE PURCHASE BEHAVIOURS IN JAPAN}

Due to physical stores closed during the emergency imposed by the Japanese government, the consumers turned to online shopping. As stated above, people at first use online platforms such as Amazon Japan and Rakuten Japan to buy masks and hand sanitizers. Rakuten Inc stated that their recent month's online marketplace sales are higher than last year. Takeshi Okazaki ${ }^{20}$, Fast Retailing's Chief Financial Officer stated that this is a big change for ecommerce to grow right now. Tokyo Governor, Yuriko Koike also requested that non-essential facilities like malls be closed in order to stop the virus from spreading. She offered up to one million yen to support businesses that shut multiple outlets.

Japanese consumers no longer hesitated to buy things online and will probably use online shopping platforms along with store-based shopping even after Covid 19 situation ends.

19 Outbreak pushes Japan Shoppers to Finally Buy Things Online, The Star, 11 April, 2020, available at: https://www.thestar.com.my/business/business-news/2020/04/11/outbreak-pushes-japan-shoppers-to-finally-buythings-online, accessed on 15 January, 2021.

20 Ibid. 
Specifically rural producers that sell agricultural products directly on online platforms are gaining momentum since consumers look for small businesses to support as these businesses are the most affected by Covid 19.

There are various efforts from online purchasing platforms to promote stay at home period and encourage consumers to buy online instead of going to a physical store. Platforms such as Rakuten Ichiba marketplace created a special hotline to give advice on topics related to product delivery delays, difficulties with payment and etc. Rakuten Ichiba also launched online seminars to ease merchant delivery standards during the pandemic. Rakuten also did a nationwide campaign to promote fresh local delicacies such as crabmeat due to feedback from regional merchants. They also contribute to a special Covid 19 fund with every purchase in the campaign. Rakuten also has been working with merchants to be a reliable source of products such as face masks, sanitizing wipes etc. to ensure no potential price-gouging or scamming happening.

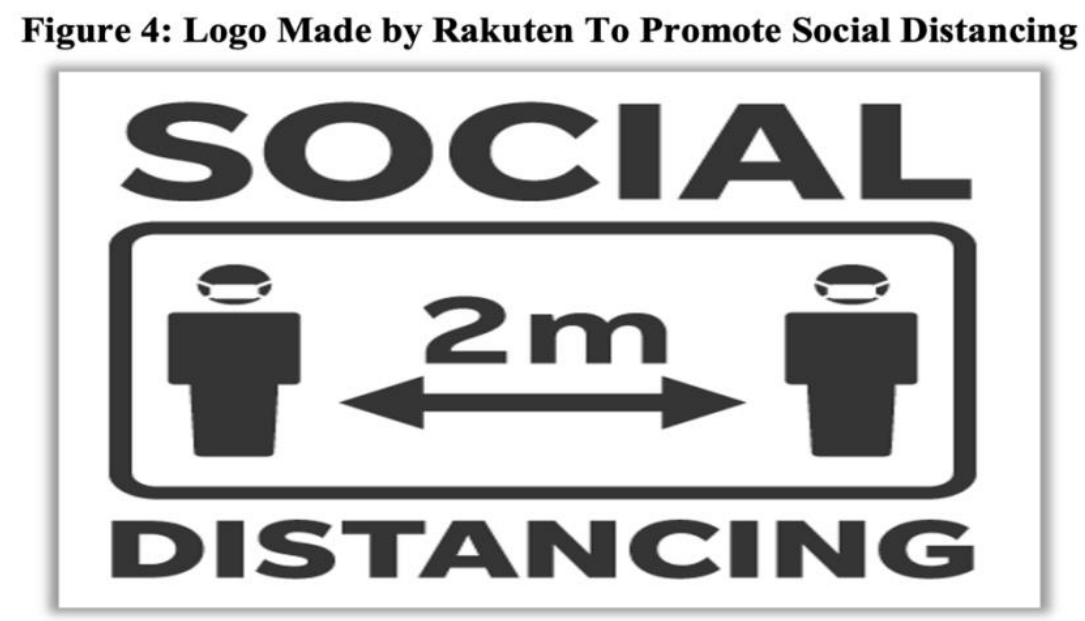

Source: Japan Association of New Economy. https://jane.or.jp/en/

Amazon Japan is also working hard to prevent the price gouging and has stated that they had blocked or removed ten thousands of item with gouged prices. Amazon is also changing the shipping method, providing an "Unattended Delivery"21 option for Amazon Japan consumers as a default delivery option in 30 different prefectures in Japan. Amazon Japan will leave consumer's items in front of their door even if they are not at home to prevent unnecessary contacts between delivery man and consumers. Consumers can choose from "Delivery box", "Gas meter", "Building receptionist" and etc. as Amazon has provided for the consumers.

Based on my personal experience, since I was in Japan last year during the pandemic until August, I had been scammed by a face mask seller from China. All the stores have no face masks so I was forced to buy it on Amazon Japan for 10000 yen plus 1500 yen shipping cost.

21 FAQs about Orders and Deliveries and the COVID-19 Virus, Amazon Japan, available at: https://www.amazon.co.jp/-/en/gp/help/customer/display.html?nodeId=GDFU3JS5AL6SYHRD, accessed on 15 January, 2021. 
However, the masks never arrived in my university's dorm. So, Amazon Japan should take a stricter approach to prevent sellers from scamming people.

\section{CHALLENGES OF ONLINE PURCHASES IN JAPAN}

Even though behavior of consumers in online purchase shows positive effects also can be accepted by the people, but there will be some challenges that happened in practicing this new norm. The pandemic gave Japan a dramatic effect on many goods, similar to other countries, and liquid soap is one in particular. In the beginning of the year, Japan shows the median price has risen sharply. Looking back over 2,800 liquid soap items on the global e-commerce product and pricing platform of Euromonitor International, the product price increase about USD1.68in two months' timeframe ${ }^{22}$. This shows that the price rises in a short time (Figure 5). The figures illustrate the effect of the dramatic announcement by Shinzo Abe about the condition of Japan due to pandemic. With the exception of shelf-stable seafood, which is likely to be due to low stock after the Oshogatsu or New Year's holiday, most of the selected categories have shown a rise in the percentage since the beginning of the year of products sold online being out of stock ${ }^{23}$.

Figure 5: Japan Liquid Soap Median SKU Price (USD)

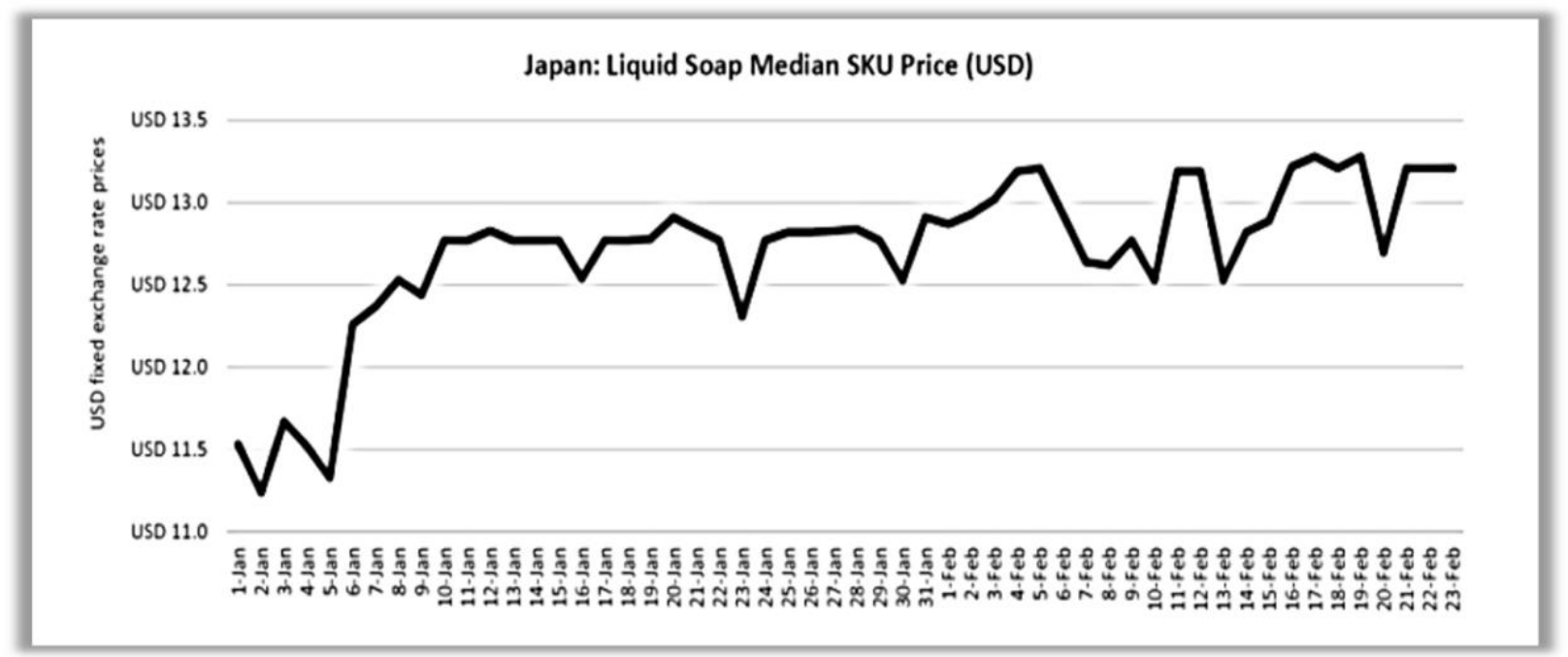

Source: Euromonitor International, available at: https://blog.euromonitor.com/coronavirus-impact-on-japans-ecommerce-product-availability-and-prices/

As shown in Figure 6, liquid soap's average price rise, is the result of increased demand, with the out-of-stock percentage of the category almost tripling within seven week, beginning at

22 Coronavirus: Impact on Japan's E-Commerce Product Availability and Prices Market Research Blog, Euromonitor International - Market Research Blog, 17 March, 2020, available at: https://blog.euromonitor.com/coronavirus-impact-on-japans-e-commerce-product-availability-and-prices/, accessed on 15 January, 2021.

${ }^{23}$ Ibid. 
5.35 percent on 5 January and reach 15.05 percent of products reported as out-of-stock on 23 February ${ }^{24}$. There has been news about essential products such as toilet paper, face masks, which are related to cleaning goods. However, by showing the overflowing purchase on these products, people will become scared and try to get the goods as they worry it will be out of stock. At the same time, the supplier will take advantage of it. As a result, non-recycled toilet paper out-ofstock percentages show a bell-shaped pattern of a rush to buy goods 'panic buying' leading to a peak of unavailable items on 26 January and 2 February and then dropping back to previous levels thanks to Japan's logistics capabilities catching up with demand or customers working through their inventories. For liquid soap, during the beginning of the COVID-19 outbreak in Japan, several other goods displayed price up and down, which can be analyzed by comparing the minimum median price to the maximum median price over the duration from 6 January to 23 February 2020. The study of prices from 6 January which is the first working day after the New Year's break, shelf-stable seafood and non-recycled toilet paper showed the greatest differences due to higher market demand prepared to cope with the situation, as well as difficulties in finding the products available.

\section{Figure 6: Japan “Out of Stock” Items as a \% of Available Online SKU's}

Japan: "Out of stock" Items as a \% of Available Online SKUs

\begin{tabular}{|l|c|c|c|c|c|c|c|c|}
\hline Category & 5-Jan & 12-Jan & 19-Jan & 26-Jan & 2-Feb & 9-Feb & 16-Feb & 23-Feb \\
\hline $\begin{array}{l}\text { All- } \\
\text { purpose } \\
\text { cleaning } \\
\text { wipes }\end{array}$ & $0.37 \%$ & $0.34 \%$ & $0.34 \%$ & $1.05 \%$ & $2.02 \%$ & $3.63 \%$ & $3.68 \%$ & $3.23 \%$ \\
\hline Bleach & $4.50 \%$ & $4.33 \%$ & $4.29 \%$ & $4.47 \%$ & $4.92 \%$ & $5.85 \%$ & $6.86 \%$ & $5.95 \%$ \\
\hline $\begin{array}{l}\text { Liquid } \\
\text { soap }\end{array}$ & $5.35 \%$ & $5.33 \%$ & $5.45 \%$ & $5.70 \%$ & $8.31 \%$ & $11.89 \%$ & $12.65 \%$ & $15.05 \%$ \\
\hline $\begin{array}{l}\text { Non- } \\
\text { recycled } \\
\text { toilet paper }\end{array}$ & $7.02 \%$ & $4.81 \%$ & $5.94 \%$ & $8.17 \%$ & $8.02 \%$ & $5.57 \%$ & $5.84 \%$ & $5.28 \%$ \\
\hline Rice & $6.15 \%$ & $3.55 \%$ & $3.68 \%$ & $3.72 \%$ & $3.71 \%$ & $3.55 \%$ & $3.62 \%$ & $3.61 \%$ \\
\hline $\begin{array}{l}\text { Shelf stable } \\
\text { seafood }\end{array}$ & $22.30 \%$ & $14.61 \%$ & $14.92 \%$ & $14.37 \%$ & $14.52 \%$ & $14.05 \%$ & $14.31 \%$ & $13.95 \%$ \\
\hline
\end{tabular}

Source: Euromonitor International. https://blog.euromonitor.com/coronavirus-an-unprecedented-impact-onjapanese-markets/

\footnotetext{
${ }^{24}$ Kathryn Hopkins, Exclusive: Verizon Media to Launch Yahoo Shops, Yahoo Finance, 22 March, 2021, available at: https://finance.yahoo.com/news/exclusive-verizon-launch-yahoo-shops-040115748.html, accessed on 25 March, 2021.
} 
Japan is known for its meticulous customers and the challenges it poses for companies looking to boost prices, so it is not a surprise that Japan showed less than a 10 percent gap in other products that have seen significant price rises in other countries. If someone or any business supplier attempts to increase essential products, they will be reported.

Other than that, online purchasing also affects retailers due to the coronavirus (Covid-19) pandemic. Retailers and carriers are struggling with rises in online orders, particularly household goods and consumables, as 57 percent of customers try to control or adjust their day-to-day operations to be as contactless as possible. The order volume for retailers that sell consumer essentials such as cleaning and household supplies has increased from a small year-over-year rise in early February which was 6.8 percent to 52 percent for the second week of March 2020 compared to the same time last year, according to fulfillment data from Convey, a last-mile technology provider ${ }^{25}$. The increase of product demand will lead to rises of product price, to fulfill consumers demand; production of a product must be consistent to prevent any congested order.

Figure 7: Japan Median Prices: 6 January - 23 February 2020

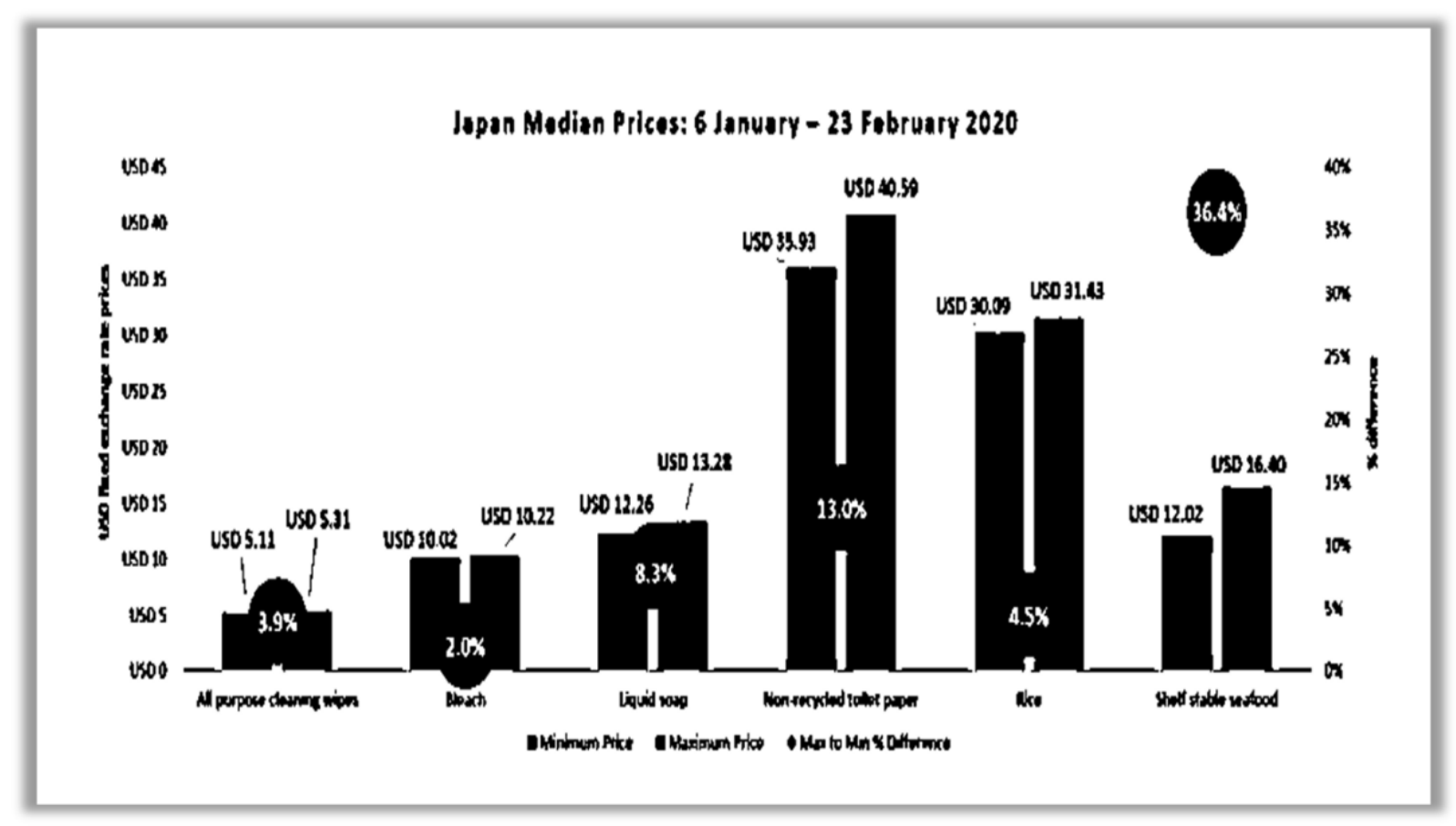

Source: Euromonitor International. https://blog.euromonitor.com/coronavirus-impact-on-japans-e-commerceproduct-availability-and-prices/

25 Louis Colombus, How COVID-19 Is Transforming E-Commerce, Forbes, 28 April 2020, available at: https://www.forbes.com/sites/louiscolumbus/2020/04/28/how-covid-19-is-transforming-ecommerce/?sh=63632da43544, accessed on 25 March, 2021. 
As we all know, Japan is a country with a high aging population rate which means that old people in Japan are increasing day by day because of some factors such as awareness of health and advanced health technologies that are served for the people of Japan.

The figure shows that the population in Japan is shrinking but the amount of the old population is still the highest in the world. The high number of the old population might be challenges for them to cope with online purchasing. Due to the coronavirus (Covid-19) pandemic, the situation in goods purchase has completely changed and it might be difficult for old people to adjust with it. The government of Japan encourages its people to stay calm, and businesses have demonstrated their logistical ability and distribution networks to ensure that those products or goods who sell out are replaced as soon as possible. However, as more businesses continue to encourage individuals to stay away from large crowds, customer behavior will change, and product pricing patterns will likely change.

Figure 8: Japan population ${ }^{26}$

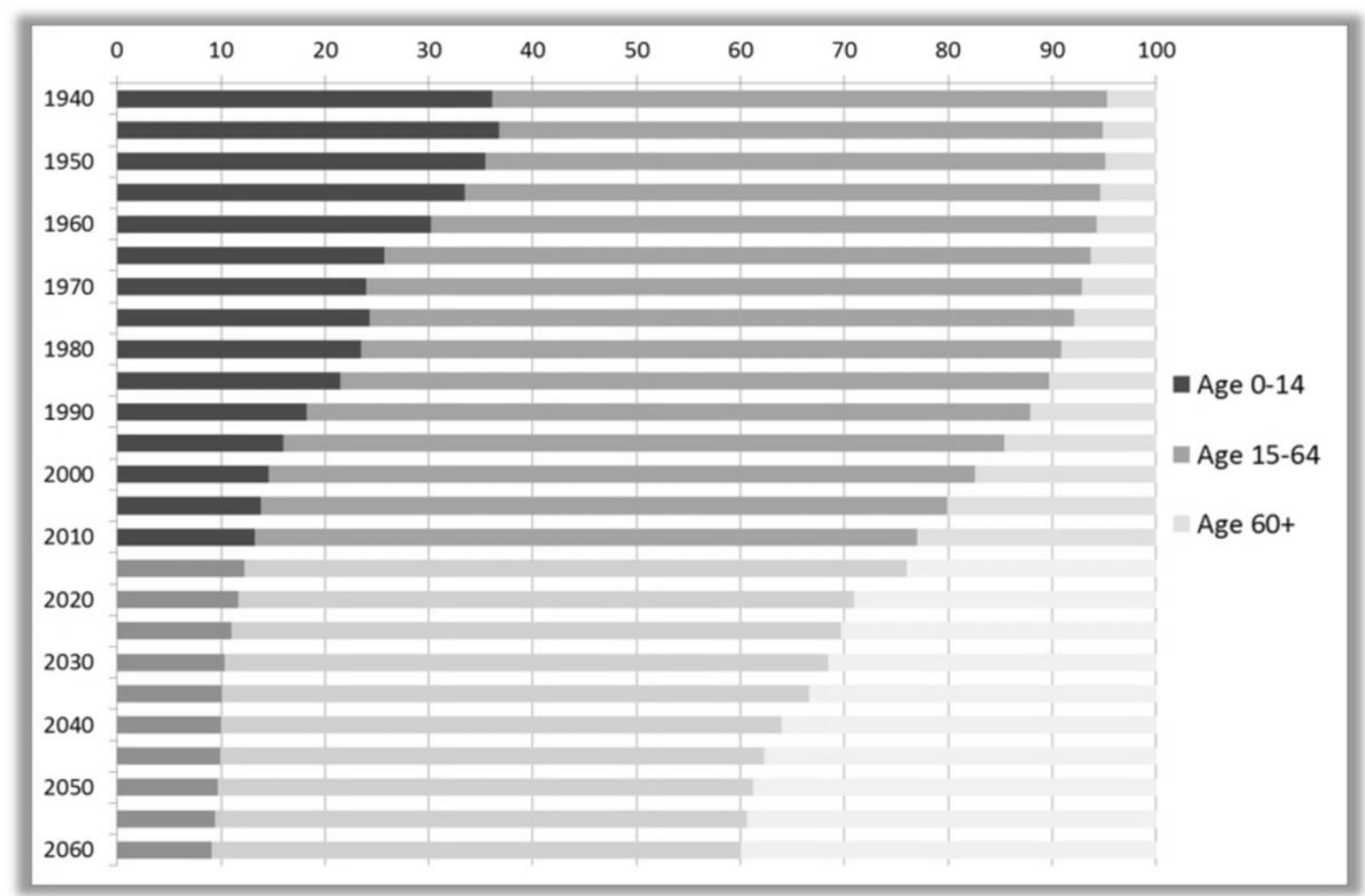

Source: World meter, Japan Population, available at: https://www.worldometers.info/world-population/japanpopulation/, accessed on January 20, 2021.

\section{CONCLUSION}

In conclusion, coronavirus (Covid-19) does give impact to online purchases behavior in Japan. Millions of online consumers are putting a huge burden on e-commerce and online retailers today by shifting their actions at the same time to opt for more time saving and convenience. The 
future of e-commerce will be determined by how they want to respond. Some want to minimize the friction that stands in the way of having the most loyal of occasional customers. And they begin by securing online identities and shielding accounts from control of the takeover. Ecommerce revenues will stabilize at a lower growth rate than they are today until state-by-state stays at home orders are lifted. In order to fully transform the retail environment and trade overall for years to come, behavioral adjustments are already in motion.

People's consumption habits have changed significantly with the spread of novel coronavirus infections. Although there has been a sharp decline in demand for services involving face-to-face interaction, such as dining out and entertainment, online consumption of products and services such as e-commerce has increased, and some expect such trends to continue once the pandemic subsides. There might be a little bit of problems from it but people will get used to it and all the challenges can be solved.

However, if the outbreak of coronavirus led many customers to make these upfront investments, after the pandemic, they would have no excuse to return to offline use. In addition, it is conceivable that simply using the internet for transactions during the pandemic could have dispelled the numerous concerns. Given this, even though the possibility of being infected with the coronavirus has vanished, online consumption "novices" will be forced to continue using the internet for transactions.

\section{REFERENCES}

Amyn Gillani, Japan: An Overlooked E-Commerce Opportunity, Entrepreneur Asia Pacific, 6 April, 2020, available at: https://www.entrepreneur.com/article/348787, accessed on 15 January, 2021.

Coronavirus: Impact on Japan's E-Commerce Product Availability and Prices Market Research Blog, Euromonitor International - Market Research Blog, 17 March, 2020, available at: https://blog.euromonitor.com/coronavirus-impact-on-japans-e-commerce-product-availabilityand-prices/, accessed on 15 January, 2021.

Covid-19 Pandemic Prompts a Digital Revolution, Japan Times, 15 April, 2020, available at: https://www.japantimes.co.jp/opinion/2020/04/15/commentary/japan-commentary/covid-19pandemic-prompts-digital-revolution/, accessed on 15 January, 2021.

Electronic Commerce, World Trade Organization (WTO), May 20, 1998, available at: https://docs.wto.org/dol2fe/Pages/SS/directdoc.aspx?filename=q:/WT/MIN98/DEC2.pdf\&Open =True, accessed on 15 January, 2021.

Familymart to Increase Stores with Amazon Lockers Sevenfold, The Japan Times, 28 December, 2020, available at: https://www.japantimes.co.jp/news/2020/12/28/business/corporatebusiness/familymart-increase-stores-amazon-lockers-sevenfold-president/, accessed on 15 January, 2021.

FAQs about Orders and Deliveries and the COVID-19 Virus, Amazon Japan, available at: https://www.amazon.co.jp/-/en/gp/help/customer/display.html?nodeId=GDFU3JS5AL6SYHRD, accessed on 15 January, 2021. 
Japan Ecommerce Market, MobileCommerce, Retail, Electronics \& Media, Toys, Hobby \& DIY, Furniture \& Appliances, Food \& Personal Care, Digital Services, Company Analysis. Renub Market Report, June 2020, available at: https://www.researchandmarkets.com/reports/5115530/japan-ecommerce-marketmobilecommerceretail?utm_source $=B W \& u t m \_m e d i u m=P r e s s R e l e a s e \& u t m \_c o d e=q k t t 2$ s\&utm_campaign $=14170$ 43+-+Japan+e-Commerce+Market+Outlook+2020-2026++Amazon+Japan\%2c+Yahoo+Japan\%2c+and+Rakuten+Earn+More+Than+50\%25+of+the+Cou ntry $\% 27 \mathrm{~s}+$ Yearly+Revenue\&utm_exec=joca220prd, accessed on 15 January, 2021.

Japan's Fussy Food Shoppers Finally Go Online Amid Pandemic, Asahi Shimbun, 30 June, 2020, available at: http://www.asahi.com/ajw/, accessed on 15 January, 2021.

Katherine Chan, Megumi Inoue, and Naomi Yamakawa, Survey: Japanese Consumer Sentiment during the Coronavirus Crisis, McKinsey \& Company, 10 December, 2020, available at: https://www.mckinsey.com/business-functions/marketing-and-sales/our-insights/surveyjapanese-consumer-sentiment-during-the-coronavirus-crisis, accessed on 15 January, 2021.

Kathryn Hopkins, Exclusive: Verizon Media to Launch Yahoo Shops, Yahoo Finance, 22 March, 2021, available at: https://finance.yahoo.com/news/exclusive-verizon-launch-yahoo-shops040115748.html, accessed on 25 March, 2021.

Louis Colombus, How COVID-19 Is Transforming E-Commerce, Forbes, 28 April 2020, available at: https://www.forbes.com/sites/louiscolumbus/2020/04/28/how-covid-19-istransforming-e-commerce/?sh=63632da43544, accessed on 15 January, 2021.

Marcia Kaplan, Japan Is an Enticing Market for Cross-border Ecommerce, PracticalEcommerce, 28 May, 2020, available at: https://www.practicalecommerce.com/japan-is-a-enticing-marketfor-cross-border-ecommerce, accessed on 15 January, 2021.

Outbreak pushes Japan Shoppers to Finally Buy Things Online, The Star, 11 April, 2020, available at: https://www.thestar.com.my/business/business-news/2020/04/11/outbreak-pushesjapan-shoppers-to-finally-buy-things-online, accessed on 15 January, 2021.

Shigemura, Jun, and Mie Kurosawa, "Mental Health Impact of the Covid-19 Pandemic in Japan," Psychological Trauma: Theory, Research, Practice, and Policy, Vol. 12, No. 5 2020, pp. 478-479.

Toyosu Market's High-End Fish Going Online, Japan Times, 2 December, 2020, available at: https://www.japantimes.co.jp/news/2020/12/02/business/toyosu-online-fish-market/, accessed on 15 January, 2021.

Tsutomu Watanabe, and Yuki Omori, "Online Consumption During the Covid-19 Crisis: Evidence from Japan," Covid Economics - Centre for Economic Policy Research Papers, Vol. 38, No. 16, 2020, pp. 218-252. 
UNIQLO Boosts Investment in E-Commerce in Japan and China, Nikkei Asia, 15 September, 2020, available at: https://asia.nikkei.com/Business/Retail/Uniqlo-boosts-investment-in-ecommerce-in-Japan-and-China, accessed on 15 January, 2021.

Wakana Morlan, Selling in Japan: E-Commerce Landscape in Japan, 2 July, 2019, available at: https://blog.btrax.com/e-commerce-trends-in-japan/, accessed on 15 January, 2021.

WHO Director-General's Opening Remarks at the Media Briefing on Covid-19, World Health Organization (WHO), 11 March, 2020, available at: https://www.who.int/directorgeneral/speeches/detail/who-director-general-s-opening-remarks-at-the-media-briefing-on-covid19---11-march-2020, accessed on 15 January, 2021. 